\title{
Anosmia in COVID-19 Associated with Injury to the Olfactory Bulbs Evident on MRI
}

\author{
(D) M.F.V.V. Aragão, (D) M.C. Leal, (D) O.Q. Cartaxo Filho, (D)T.M. Fonseca, and (DM.M. Valença
}

O- $=$

\begin{abstract}
SUMMARY: Patients with coronavirus disease 2019 (COVID-19) may have symptoms of anosmia or partial loss of the sense of smell, often accompanied by changes in taste. We report 5 cases ( 3 with anosmia) of adult patients with COVID-19 in whom injury to the olfactory bulbs was interpreted as microbleeding or abnormal enhancement on MR imaging. The patients had persistent headache $(n=4)$ or motor deficits $(n=1)$. This olfactory bulb injury may be the mechanism by which the Severe Acute Respiratory Syndrome coronavirus 2 causes olfactory dysfunction.
\end{abstract}

ABBREVIATIONS: COVID-19 = coronavirus disease 2019; SARS-CoV-2 = Severe Acute Respiratory Syndrome coronavirus 2

C oronavirus has the human respiratory system as its main target but also has neuroinvasive capabilities and can spread from the respiratory tract to the CNS. ${ }^{1-3}$ Therefore, patients with coronavirus disease 19 (COVID-19) may present with neurologic symptomatology with repercussions on imaging examinations, ${ }^{4-18}$ and these have been described in association with ischemic infarct, ${ }^{8,9}$ hemorrhage, ${ }^{11}$ acute hemorrhagic necrotizing encephalopathy, ${ }^{10}$ cerebral venous thrombosis, ${ }^{13}$ and diffuse leukoencephalopathy with microhemorrhage. ${ }^{15}$

Transmission from person to person occurs mainly by direct contact or droplets spread by coughing or sneezing by an infected individual with Severe Acute Respiratory Syndrome coronavirus 2 (SARS-CoV-2). ${ }^{5,19}$ Symptoms of COVID-19 usually appear after an incubation period of about 5 days. The most common symptoms are fever, cough, fatigue, headache, and dyspnea. ${ }^{5,19,20}$ In the most severe cases, patients may develop pneumonia, acute respiratory failure, distress syndrome, and acute heart problems.

Anosmia or partial loss of the sense of smell, usually accompanied by changes in taste, is a frequent symptom that helps in the diagnosis of COVID-19..$^{21-28}$ It is often a transitory

Received May 20, 2020; accepted after revision June 1.

From the Universidade Federal de Pernambuco (M.F.V.V.A., M.C.L., M.M.V.), Recife, Brazil; Centro Diagnostico Multimagem (M.F.V.V.A.), Recife, Brazil; and Real Hospital de Beneficencia Portuguesa (M.C.L., O.Q.C.F., T.M.F.), Recife, Brazil.

Please address correspondence to Maria Fatima Viana Vasco Aragão, MD, Rua Frei Matias Teves, 194, Ilha do Leite, Recife, PE, Brazil, 50070-450; e-mail:

fatima.vascoaragao@gmail.com

- Indicates open access to non-subscribers at www.ajnr.org

Indicates article with supplemental on-line table.

http://dx.doi.org/10.3174/ajnr.A6675 phenomenon, lasting just a few weeks. ${ }^{21}$ However, the mechanism by which anosmia occurs has not yet been established. $^{29}$

The hypothesis is that the virus enters the central nervous system through the first neurons of the olfactory pathway, also called olfactory sensory neurons, located in the olfactory mucosa. The olfactory mucosa is a specialized neuroepithelium located in the highest portion of the nasal cavity in direct contact with the external environment below to the cribriform plate. ${ }^{1}$ Therefore, the virus crosses the cribriform plate to reach the olfactory bulbs, which contain the second olfactory neurons. ${ }^{1,30}$

There are currently only 2 reports evaluating olfactory bulb imaging, and they are discordant. ${ }^{18,31}$ The first report showed bilateral inflammatory obstruction of the olfactory clefts that was confirmed on MR imaging of the nasal cavity, but no anomalies of the olfactory bulbs and tracts. ${ }^{31}$ The second study reported a case with anosmia evaluated with 3D-CISS T2WI, which demonstrated severe enlargement and an abnormal high signal intensity on T2, being interpreted as bilateral olfactory bulb edema and also olfactory cleft mild edema. ${ }^{18}$ The control MR imaging (D24) showed a reduction in the volume of the bulbs. ${ }^{18}$

To our knowledge, no other report has evaluated the characteristics of the olfactory bulb, especially using fat-suppressed T1WI. Also, no report evaluates and shows the presence of bleeding or a break in the blood-brain barrier in the olfactory bulbs and tracts as the possible pathophysiology of olfactory neuropathy associated with COVID-19.

Thus, in this study, the authors demonstrate by MR imaging that a possible mechanism by which the SARS-CoV-2 causes olfactory dysfunction is by affecting, intracranially, the olfactory bulbs by a likely microvascular phenomenon. 


\section{MATERIALS AND METHODS}

This retrospective study was approved by the institutional review board of the ethics committee of Universidade Federal de Pernambuco, Brazil. Informed consent was waived.

All scans were initially analyzed by the institution's own neuroradiologists. Subsequently, all images were reviewed independently by 2 neuroradiologists (M.F.V.V.A. and O.Q.C.F, who were certified by the Ministry of Education and Culture of Brazil and the Brazilian College of Radiology) with 30 and 18 years, respectively, of neuroradiology experience, with no discordant results. MR imaging was indicated mainly because of a persistent incapacitating headache.

The intensity of the olfactory bulbs is defined as normal when the bulbs have the same cortical intensity, as typically seen in healthy controls. Abnormal olfactory bulb intensity is defined when the bulb is more hyperintense than the cortex on T1WI and STIR.

After gadolinium injection on T1WI, enhancement of the olfactory bulbs is defined when they become more hyperintense in comparison with their intensity on pregadolinium T1WI. However, when there is only the postgadolinium T1WI and the bulb is more hyperintense than the normal cortex, these features represent olfactory bulb intensity abnormality and may be an enhancement or microbleeding (methemoglobin), as interpreted in the present study. Microbleeding (methemoglobin) in the olfactory bulb is considered when there is a hyperintense olfactory bulb, compared with the normal cortex or the normal contralateral bulb, on pregadolinium fat-suppressed T1WI.

Brain MR imaging of patients with COVID-19 was evaluated from April 1, 2020, to May 18, 2020. Five patients were included in this study because their brain MRIs assessed their olfactory bulbs appropriately, with at least 2 sequences with thin slices examining the anterior cranial fossa. All 5 patients were evaluated with 2 coronal sequences with thin slices: postcontrast fat-suppressed T1WI and STIR. Only 1 patient also had thin-slice pregadolinium fat-suppressed T1WI.

The brain MRIs of the patients were performed on two $1.5 \mathrm{~T}$ machines with the main technical parameters of the sequences described as follows. The coronal fat-suppressed T1WI (spectral presaturation with inversion recovery) parameters were, respectively, on both MR imaging machines the following: TR/ $\mathrm{TE}=561-605 / 15-9 \mathrm{~ms}$, matrix $=256-88, \mathrm{FOV}=190-150 \mathrm{~mm}$, thickness $=3 \mathrm{~mm}, 3.5-\mathrm{mm}$ section, coronal orientation, bandwidth $=181-96.6 \mathrm{~Hz}$, time $=3.39-4.49$ minutes, NEX $=1-3$.

The coronal STIR sequence had the following parameters in each MR imaging machine, respectively: TR/TE $=4000-2650 / 51-$ $90 \mathrm{~ms}$, TI $=180 \mathrm{~ms}$, matrix $=256-224, \mathrm{FOV}=190-150 \mathrm{~mm}$, thickness $=3-3.45 \mathrm{~mm}$, section orientation = coronal, bandwidth $=190-232.4 \mathrm{~Hz}$, time $=2.46-3.42$ minutes, and NEX $=1-2$.

\section{RESULTS}

All 5 patients with COVID-19 (On-line Table) had fever, headache, and cough. The medical indications for the performance of MR imaging were persistent headache $(n=4)$ or motor deficit $(n=1)$. All 5 patients had injury to the olfactory bulbs demonstrated by MR imaging with the following sequences: coronal

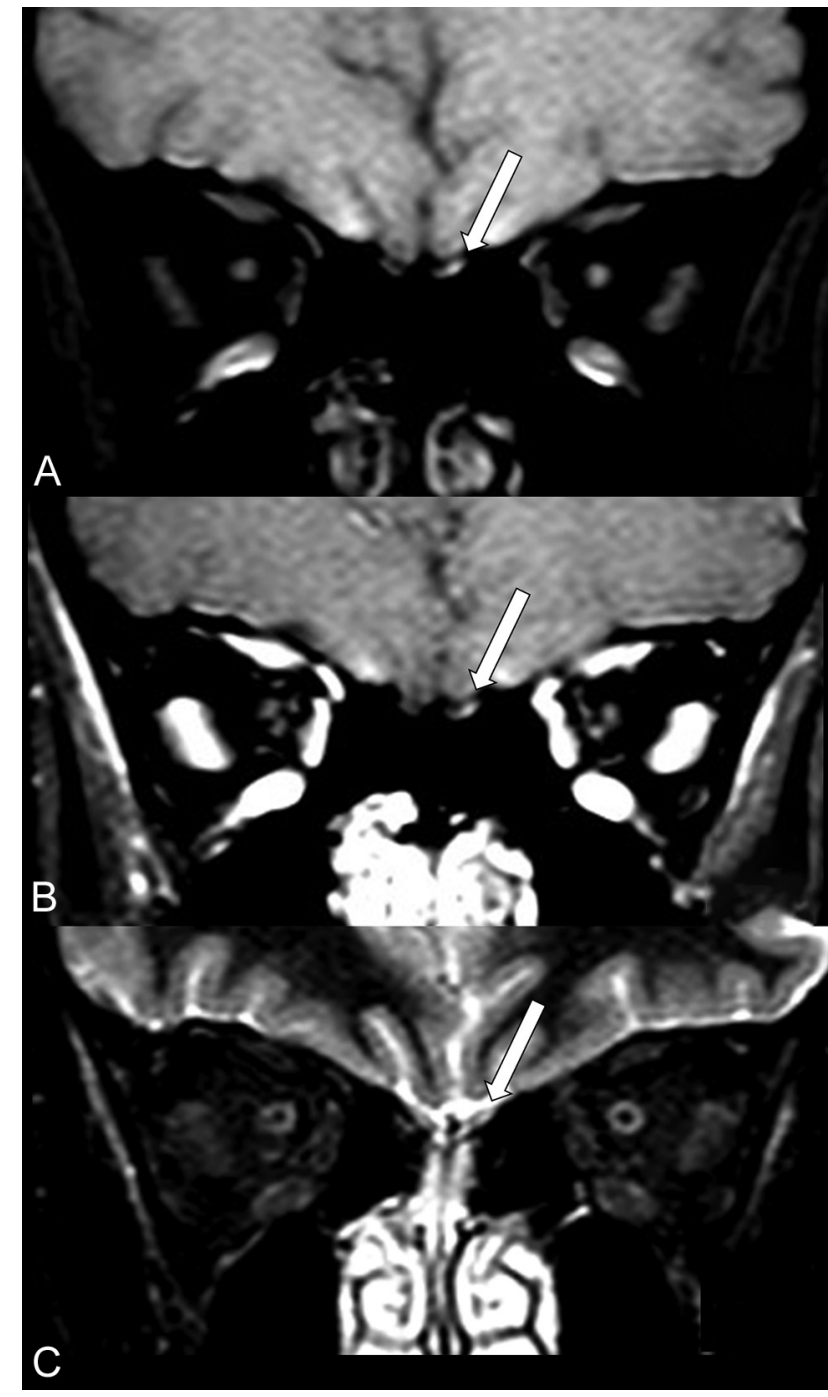

FIG 1. MR imaging shows probably microbleeding (methemoglobin) in the left olfactory bulb of a patient (case 1) with COVID-19 and anosmia. The left olfactory bulb (long arrows) has partial hyperintensity on precontrast fat-suppressed TIWI (A) and also on postcontrast fatsuppressed TIWI (B) and STIR (C).

pre-contrast (Fig $1 A$ ) and post-contrast fat suppression T1WI (Figs $1 B$ and $2 A,-D$ ) and coronal STIR (Fig 1C).

The only patient who had pregadolinium fat-suppressed T1WI (case 1) showed a small hyperintensity in the left olfactory bulb (Fig $1 A$ ), which remained hyperintense on the postgadolinium sequence (Fig $1 B$ ) and also on STIR (Fig $1 C$ ). This finding was suggestive of a small area of methemoglobin in the left olfactory bulb in this patient with anosmia.

In the 4 patients who did not have a pregadolinium sequence, we did not have information about anosmia in 1 patient (Fig 2A; case 2), and 2 of them with anosmia (Fig 2B, -C; Cases 3 and 4) showed hyperintensity suggestive of enhancement of both olfactory bulbs following gadolinium injection. However, only in the patient with COVID-19 without clinical anosmia (case 5) was there a suggestive enhancement in the left olfactory bulb (Fig $2 D)$. The case 5 had a negative result of the CSF real-time RTPCR for SARS-CoV-2. The differential diagnosis in these cases is 


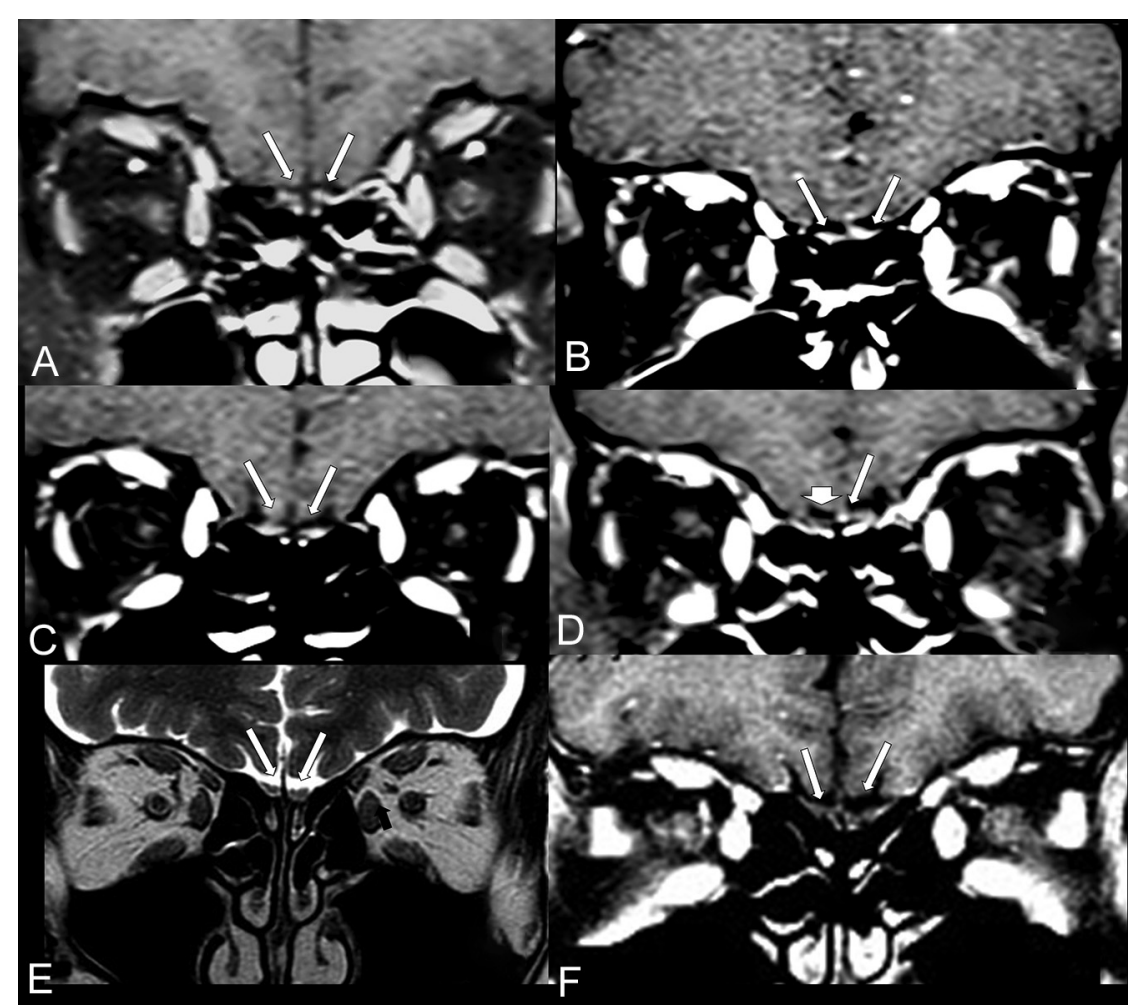

FIG 2. The coronal postcontrast fat-suppressed TIWI shows hyperintensity suggestive of enhancement or methemoglobin in the olfactory bulbs of 4 patients with COVID-19 (A-D; cases $2-5)$ compared with a healthy patient with normal olfactory bulbs $(E$ and $F)$. The coronal postcontrast fat-suppressed TIWI in 3 patients with COVID-19 (A-C; cases 2-4) shows that both olfactory bulbs (long arrows) are small oval images that are hyperintense with contrast, having signal intensity higher than the intensity of the cortex. D, A patient (case 5) with COVID-19 shows hyperintensity only on the left bulb (long arrow), the right olfactory bulb being normal (short arrow). In a healthy 60-year-old man, the coronal T2WI (E) and the postcontrast fat-suppressed TTWI $(F)$ demonstrate normal olfactory bulbs (long arrows), which are isointense to the cortex and normally hypointense on postgadolinium sequence $(F)$.

mainly microbleeding (methemoglobin) because the pregadolinium sequence was not performed. Coronal STIR of the anterior cranial fossa did not show any abnormality in the olfactory bulbs in these 4 patients.

MR imaging of a healthy individual was used as a comparative control (Fig $2 E,-F$ ) to demonstrate that the normal olfactory bulbs do not enhance and are isointense to the cerebral cortex.

\section{DISCUSSION}

This case series demonstrates abnormal intensity of the olfactory bulbs in 5 adult patients with COVID-19, three of whom had anosmia. In 1 patient (case 1 ), the abnormal intensity could represent microbleeding (methemoglobin). However, in the other 4 patients, it could represent abnormal enhancement or microbleeding (methemoglobin) because they only underwent the sequence after injection of gadolinium in fat-suppressed T1WI.

Previously, it was demonstrated, using an experimental mouse model, that the SARS-CoV could travel from the nose to the olfactory bulb. ${ }^{32}$ Regarding the SAR-CoV infection, there was a time delay of about 60 hours from the time of nasal infection until the detection of the virus in the olfactory bulb. ${ }^{1,32}$
The literature has already reported that some other viruses can use the olfactory nerve as a shortcut into the CNS, such as influenza A virus, herpesviruses, poliovirus, paramyxoviruses, vesicular stomatitis virus, rabies virus, parainfluenza virus, adenoviruses, Japanese encephalitis virus, West Nile virus, chikungunya virus, La Crosse virus, mouse hepatitis virus, and bunya viruses. ${ }^{30}$ van Riel et $\mathrm{al}^{30}$ have reported that "Viral infection of the CNS can lead to damage from infection of nerve cells per se, from the immune response, or from a combination of both. Clinical consequences range from nervous dysfunction in the absence of histopathological changes to severe meningoencephalitis and neurodegenerative disease." However, to our knowledge, no study evaluated and documented, by brain MR imaging, the abnormalities such as microbleeding and/or enhancement in the olfactory bulbs occurring in these other kinds of viruses.

Probably, the impairment of olfactory function is much more frequent in COVID-19 because, strictly speaking, unilateral anosmia can only be detected through a detailed physical examination. The patient hardly perceives unilateral anosmia.

Recognizing this hypersignal in the olfactory bulbs on the thin slices of preand/or postgadolinium fat-suppressed T1WI, identified in this study, may help to suggest or support the etiologic diagnosis of COVID-19 during and after this new pandemic.

Thus, we suggest, henceforth, including in the routine brain MR imaging protocol at least a sequence with coronal thin-slice pre- and/or postgadolinium fat-suppressed T1WI in the anterior fossa of the cranium. This feature will be more important in cases of refractory headache associated or not with other symptoms and signs such as fever and anosmia.

The weakness of this work is that it is a retrospective study with only a few cases in which it was possible to evaluate the olfactory bulbs. Brain MR imaging of patients with COVID-19 has not been routinely scheduled to adequately evaluate the olfactory bulbs because other neurologic complications were being investigated. The distortion at the air-tissue interface in fat-suppressed T1WI makes the findings somewhat difficult to interpret, but it seems that the images are true abnormal lesions along the olfactory bulbs. Future prospective studies geared to evaluating the olfactory bulbs with a larger sample size will be needed to confirm our findings.

In conclusion, the authors demonstrated by MR imaging that a possible mechanism by which the SARS-CoV-2 causes olfactory 
dysfunction is by affecting, intracranially, the olfactory bulbs, with development of a microvascular phenomenon and injury such as microbleeding and/or a blood-brain barrier break. This seems to be the first time that a neuroimaging study has documented this type of olfactory bulb injury in patients with COVID-19.

\section{REFERENCES}

1. Fodoulian L, Tuberosa J, Rossier D, et al. SARS-CoV-2 receptor and entry genes are expressed by sustentacular cells in the human olfactory neuroepithelium. bioRxiv 2020. https://www.biorxiv.org/ content/10.1101/2020.03.31.013268v1. Accessed May 12, 2020

2. Desforges M, Le Coupanec A, Dubeau P, et al. Human coronaviruses and other respiratory viruses: underestimated opportunistic pathogens of the central nervous system? Viruses 2019;12:14 CrossRef Medline

3. Morris M, Zohrabian VM. Neuroradiologists, be mindful of the neuroinvasive potential of COVID-19. AJNR Am J Neuroradiol 2020 Apr 30. [Epub ahead of print] CrossRef Medline

4. Montalvan V, Lee J, Bueso T, et al. Neurological manifestations of COVID-19 and other coronavirus infections: a systematic review. Clin Neurol Neurosurg 2020;194:10592 CrossRef Medline

5. Whittaker A, Anson M, Harky A. Neurological Manifestations of COVID-19: A review. Acta Neurol Scand 2020;142:14-22 CrossRef Medline

6. Ahmad I, Rathore FA. Neurological manifestations and complications of COVID-19: a literature review. J Clin Neurosci 2020 May 6. [Epub ahead of print] CrossRef Medline

7. Asadi-Pooya AA, Simani L. Central nervous system manifestations of COVID-19: a systematic review. J Neurol Sci 2020;413:116832 CrossRef Medline

8. Goldberg MF, Cerejo R, Tayal AH. Cerebrovascular disease in COVID-19. AJNR Am J Neuroradiol 2020 May 14. [Epub ahead of print] CrossRef Medline

9. Aggarwal G, Lippi G, Michael Henry B. Cerebrovascular disease is associated with an increased disease severity in patients with coronavirus disease 2019 (COVID-19): a pooled analysis of published literature. Int J Stroke 2020;15:385-89 CrossRef Medline

10. Poyiadji N, Shahin G, Noujaim D, et al. COVID-19-associated acute hemorrhagic necrotizing encephalopathy: CT and MRI features. Radiology 2020 March 31. [Epub ahead of print] CrossRef Medline

11. Franceschi AM, Ahmed O, Giliberto L, et al. Hemorrhagic posterior reversible encephalopathy syndrome as a manifestation of COVID-19 infection. AJNR Am J Neuroradiol 2020 May 21. [Epub ahead of print] CrossRef Medline

12. Poillon G, Obadia M, Perrin M, et al. Cerebral venous thrombosis associated with COVID-19 infection: causality or coincidence? $J$ Neuroradiol 2020 May 10. [Epub ahead of print] CrossRef Medline

13. Garaci F, Di Giuliano F, Picchi E, et al. Venous cerebral thrombosis in COVID-19 patient. J Neurol Sci 2020;414:116871 CrossRef Medline

14. Hughes C, Nichols T, Pike M, et al. Cerebral venous sinus thrombosis as a presentation of COVID-19. Eur J Case Rep Intern Med 2020;7:001691 CrossRef Medline

15. Radmanesh A, Derman A, Lui YW, et al. COVID-19-associated diffuse leukoencephalopathy and microhemorrhages. Radiology 2020 May 21. [Epub ahead of print] CrossRef Medline
16. Mahammedi A, Saba L, Vagal A, et al. Imaging in neurological disease of hospitalized COVID-19 patients: an Italian multicenter retrospective observational study. Radiology 2020 May 21. [Epub ahead of print] CrossRef Medline

17. Karimi-Galougahi M, Yousefi-Koma A, Bakhshayeshkaram M, et al. ${ }^{18}$ FDG PET/CT scan reveals hypoactive orbitofrontal cortex in anosmia of COVID-19. Acad Radiol 2020 May 3. [Epub ahead of print] CrossRef Medline

18. Laurendon T, Radulesco T, Mugnier J, et al. Bilateral transient olfactory bulbs edema during COVID-19-related anosmia. Neurology 2020 May 22. [Epub ahead of print] CrossRef Medline

19. Weiss $P$, Murdoch DR. Clinical course and mortality risk of severe COVID-19. Lancet 2020;395:1014-15 CrossRef Medline

20. Zhou F, Yu T, Du R, et al. Clinical course and risk factors for mortality of adult inpatients with COVID-19 in Wuhan, China: a retrospective cohort study. Lancet 2020;395:1054-62 CrossRef Medline

21. Hopkins C, Surda P, Whitehead E, et al. Early recovery following new onset anosmia during the COVID-19 pandemic: an observational cohort study. J Otolaryngol Head Neck Surg 2020;49:26 CrossRef Medline

22. Kaye R, Chang CW, Kazahaya K, et al. Anosmia reporting tool: initial findings. Otolaryngol Head Neck Surg 2020 Apr 28. [Epub ahead of print] CrossRef Medline

23. Gane SB, Kelly C, Hopkins C. Isolated sudden onset anosmia in COVID-19 infection: a novel syndrome? Rhinology 2020;58:299301 CrossRef Medline

24. Ghiasvand F, SeyedAlinaghi S. Isolated anosmia as a presentation of COVID-19: an experience in a referral hospital. Infect Disord Drug Targets 2020 May 20. [Epub ahead of print] CrossRef Medline

25. Heidari F, Karimi E, Firouzifar M, et al. Anosmia as a prominent symptom of COVID-19 infection. Rhinology 2020;58:302-03 CrossRef Medline

26. Lechien JR, Barillari MR, Jouffe L, et al. Anosmia Is a key symptom of COVID-19 infection and should be used as a diagnostic tool. Ear Nose Throat J 2020 May 21. [Epub ahead of print] CrossRef Medline

27. Villalba NL, Maouche Y, Ortiz MB, et al. Anosmia and dysgeusia in the absence of other respiratory diseases: should COVID-19 infection be considered? Eur J Case Rep Intern Med 2020;7:001641 CrossRef Medline

28. Marinosci A, Landis BN, Calmy A. Possible link between anosmia and COVID-19: sniffing out the truth. Eur Arch Otorhinolaryngol 2020 Apr 17. [Epub ahead of print] CrossRef Medline

29. Vaira LA, Salzano G, Fois AG, et al. Potential pathogenesis of ageusia and anosmia in COVID-19 patients. Int Forum Allergy Rhinol 2020 Apr 27. [Epub ahead of print] CrossRef Medline

30. van Riel D, Verdijk R, Kuiken T. The olfactory nerve: a shortcut for influenza and other viral diseases into the central nervous system. J Pathol 2015;235:277-87 CrossRef Medline

31. Eliezer M, Hautefort C, Hamel AL, et al. Sudden and complete olfactory loss function as a possible symptom of COVID-19. JAMA Otolaryngol Head Neck Surg 2020 Apr 8. [Epub ahead of print] CrossRef Medline

32. Netland J, Meyerholz DK, Moore S, et al. Severe acute respiratory syndrome coronavirus infection causes neuronal death in the absence of encephalitis in mice transgenic for human ACE2. $J$ Virol 2008;82:7264-75 CrossRef Medline 